\title{
PERBEDAAN POLA ASUH DAN STATUS GIZI ANAK BALITA SEBELUM DAN SETELAH PENYULUHAN POLA ASUH
}

\author{
Tri Marta Fadhilah ${ }^{1^{*}}$ \\ 1. Program Studi S1 Ilmu Gizi, STIKes Mitra Keluarga, Bekasi-Indonesia \\ *Korespondensi: Tri Marta Fadhilah | STIKes Mitra Keluarga | martafadhilah88@ gmail.com
}

\begin{abstract}
Abstrak
Pendahuluan: Pola asuh anak berupa pengetahuan sikap dan perilaku ibu dalam kedekatannya dengan anak, seperti: pola pemberikan makanan sehat, praktek kebersihan dan sanitasi lingkungan, serta perawatan balita sakit. Tujuan penelitian ini adalah untuk menganalisis perbedaan sebelum dan setelah penyuluhan pola asuh (pola pemberian makanan sehat, praktek kebersihan dan sanitasi lingkungan, perawatan balita sakit) dan status gizi balita.

Metode: Metode yang digunakan dalam penelitian ini adalah pre dan post tes dengan uji paired t-test dan uji bivariate correlatian.

Hasil: Hasil dari penelitian ini didapat sebelum penyuluhan pola asuh, pola pemberian makanan sehat memiliki poin sebesar 52.4, praktek kebersihan dan sanitai lingkungan memiliki poin sebesar 62.73, serta perawatan balita sakit memiliki poin sebesar 55.27. Nilai Z-skor BB/TB adalah 1.30. Setelah diberikan penyuluhan pola asuh selama 3 bulan terjadi peningkatan dalam pola pemberian makanan sehat menjadi 89.8 poin, praktek kebersihan dan sanitasi lingkungan menjadi 85.42 poin, serta perawatan balita sakit menjadi 82.84 poin. Nilai Z-skor BB/TB adalah 0.43 poin.
\end{abstract}

Kesimpulan: Penyuluhan pola asuh dalam pola pemberian makanan sehat, praktek kebersihan dan sanitasi lingkungan, serta perawatan balita sakit memiliki hubungan positif dengan status gizi balita.

Kata Kunci: Balita, Penyuluhan pola asuh, Status gizi

Diterima 17 Agustus 2019; Accepted 30 Desember 2019

\section{PENDAHULUAN}

Pola asuh anak berupa sikap dan perilaku ibu atau pengasuh lain dalam kedekatannya dengan anak, seperti: pola pemberian makanan sehat, praktek kebersihan dan sanitasi lingkungan, serta perawatan balita sakit. Hal ini berhubungan dengan keadaan kesehatan (fisik dan mental), status gizi, pendidikan, penghasilan, pengetahuan, ketrampilan tentang pengasuhan anak yang baik, dan peran dalam keluarga atau masyarakat, dari si ibu dan pengasuh anak (Sunarti, 2004). Salah satu upaya yang dapat dilakukan untuk mengurangi angka prevalensi balita kurang gizi adalah melakukan kegiatan penyuluhan pola asuh ibu dengan cara berdiskusi langsung kepada para ibu yang mempunyai balita kurang gizi. Maksud dari kegiatan ini pada hakekatnya adalah untuk menyampaikan pesan kesehatan kepada masyarakat, kelompok atau individu, agar dapat memperoleh pengetahuan kesehatan yang lebih baik (Notoatmodjo, 2010). Akhirnya kegiatan pendampingan pola asuh ibu akan berdampak pada peningkatan status gizi balita sehingga menurunkan morbiditas dan mortalitas yang bermakna.

Peningkatan status gizi masyarakat merupakan salah satu upaya penting untuk meningkatkan kesehatan ibu hamil, menurunkan angka kematian ibu, bayi dan balita, meningkatkan kemampuan tumbuh kembang fisik anak, mental dan sosial anak untuk meningkatkan produktivitas kerja serta prestasi akademik maupun prestasi olah raga. Berdasarkan data Survey Nasional tahun 2007 menunjukkan bahwa terjadi penurunan yaitu mencapai 18.4\%, (gizi buruk 5.4\% dan gizi kurang 13\%), kemudian balita stunting (pendek) mencapai 36.8\%, balita wasting (kurus) mencapai 4.3\% dan gizi lebih 4.3\% (Depkes RI, 2007). Sementara itu, berdasarkan data Survey Nasional tahun 2010 menunjukkan bahwa prevalensi balita kurang gizi (berat badan kurang) sebesar 18,0\% diantaranya $4.9 \%$ dengan gizi buruk. Sedangkan prevalensi balita pendek (stunting) sebesar 35.6\%, dan prevalensi balita kurus (wasting) adalah 13.3\% (Depkes RI, 2010). Menurut data Profil Jawa Tengah (2011), bahwa permasalahan gizi pada anak balita yaitu gizi kurang sebesar 5.35\% dan gizi buruk sebesar 3.187 (0.10\%) menurun apabila dibandingkan tahun 2010 sejumlah 3.514 (0.18\%), demikian pula persentase balita gizi buruk mendapatkan perawatan tahun 2011 sebesar 100\% jauh lebih meningkat dibandingkan tahun 2010 sebesar 93.28\%. Menurut data Dinas Kesehatan Kabupaten Karangannyar (2012) di desa Bangsri terdapat 41 (14.18\%) balita gizi kurang dan balita gizi buruk sebanyak $16(5.53 \%)$ dari jumlah balita yang ada di Desa Bangsri yaitu 289 balita. Menurut data Dinas 
Kesehatan Kabupaten Karangannyar (2012) di desa Karang terdapat 25 balita gizi kurang dan balita gizi buruk sebanyak 10 dari jumlah balita yang ada di Desa Karang yaitu 150 balita.

Dari data diatas disimpulkan bahwa masalah balita gizi kurang harus segera ditangani agar dapat menurunkan morbiditas dan mortalitas yang berlanjut pada penurunan kualitas Status Gizi Balita. Pengaruh kegiatan penyuluhan pola asuh ibu terhadap peningkatan status gizi balita dapat diterangkan lewat alur bahasan ilmu gizi yang merupakan cabang ilmu kedokteran yang mengedepankan keserasian antara pola pemberian makanan sehat, praktek kebersihan dan sanitasi lingkungan, serta perawatan balita sakit (Depkes RI, 2010). Diharapkan dengan melakukan / menerapkan pola pemberian makanan sehat, praktek kebersihan dan sanitasi lingkungan, serta perawatan balita sakit tersebut maka akan terjadi peningkatan status gizi balita, sehingga dapat menurunkan morbiditas dan mortalitas balita yang selanjutnya dapat mempersiapkan Balita dengan Status Gizi baik yang berkualitas demi kejayaan bangsa.

Berdasarkan alasan diatas maka peneliti tertarik untuk melakukan penelitian dengan judul "Perbedaan Pola asuh dan Status Gizi Anak Balita Sebelum dan Setelah Penyuluhan Pola Asuh”.

\section{METODE}

Jenis penelitian ini adalah kuantitatif. Metode yang akan digunakan adalah Pre Experimental Desain dengan rancangan one group pre-test and post-test desain dimana dalam penelitian ini tidak ada (kontrol). Variabel independent penelitian ini adalah kegiatan penyuluhan pola asuh ibu. Dan variabel dependent penelitian ini adalah status gizi balita. Populasi dalam penelitian ini adalah semua anak balita kurang gizi dengan usia 0 bulan sampai 60 bulan ( 5 tahun), berjumlah total 80 anak balita. Jika dalam satu keluarga terdapat dua anak yang memiliki usia 0-60 bulan, maka diambil semua. Sampel yang diambil dengan menggunakan metode stratified random sampling, berjumlah 45 balita. Penelitian ini mengambil lokasi di Desa Bangsri dan Desa Karang Kecamatan Karangpandan Kabupaten Karanganyar Jawa Tengah dengan alasan karena di Desa Bangsri dan Desa Karang masih banyak anak balita yang mengalami status gizi kurang (20\%).

Pengukuran pola asuh ibu (pola pemberian makanan sehat, praktek kebersihan dan sanitasi lingkungan serta perawatan anak balita sakit) menggunakan kuesioner yang berisi pertanyaan-pertanyaan yang berkaitan dengan kegiatan penyuluhan pola asuh ibu yang diteliti dengan menggunakan sistem skoring berdasarkan jawaban, bila benar/sesuai yang diinginkan 1(satu), dan bila salah/tidak sesuai yang diinginkan diberikan nilai 0 (nol) (Khomsan, 2000). Berdasarkan hasil penelitian bahwa jumlah anggota keluarga 1-3 orang adalah 15 responden (33\%), yang memiliki anggota keluarga 4-6 orang adalah 25 responden (56\%), dan yang jumlah anggota keluarga 7-9 orang adalah 5 responden (11\%). Berdasarkan hasil penelitian bahwa umur balita kategori <20 bulan adalah 8 balita (18\%), kategori 20-40 bulan adalah 14 balita (31\%), dan kategori 40-60 bulan adalah 23 balita (51\%). Berdasarkan hasil penelitian bahwa jenis kelamin balita perempuan adalah 23 balita (51\%) dan jenis kelamin balita laki-laki ada 22 balita (49\%).Status Gizi adalah suatu keadaan keseimbangan antara konsumsi dan penyerapan zat gizi yang dinilai berdasarkan ukuran antropometri yaitu rasio berat badan menurut tinggi badan (BB/TB)yang diinterpretasikan dengan nilai ZSkor. Data diolah dengan menggunakan Child Growth Standard WHO 2005.

Teknik pengumpulan data dalam peneilitian ini adalah dengan instrumen. Kuesioner yang berisi pertanyaan yang disusun menurut variabel yang diteliti yaitu: pola pemberian makanan sehat, praktek kebersihan dan sanitasi lingkungan, serta perawatan anak balita sakit. Selain itu instrumen yang digunakan yaitu timbangan berat badan dacin dan alat pengukur tinggi badan microtoa, serta formulir informed concent untuk mendapatkan persetujuan ibu anak balita dalam mengikuti kegiatan penyuluhan pola asuh ibu. Data dilakukan analisis paired t-test dan uji lanjut dengan uji paired correlation t-test dengan taraf nyata 95\% $(\mathrm{p}<0.05)$. Hasil penelitian secara statistik berbeda signifikan jika $\mathrm{p}<0.05$ dan berpengaruh signifikan jika $\mathrm{p}<0.05$.

\section{HASIL}

\section{Deskriptif Responden}

Tingkat pendidikan ibu

Berdasarkan hasil perhitungan bahwa tingkat pendidikan ibu yang tamat SD adalah 16 responden (36\%), yang tamat SLTP adalah 24 responden (53\%), dan yang tidak tamat SD adalah 5 responden (11). 
Tingkat pendapatan keluarga

Berdasarkan hasil penelitian bahwa tingkat pendapatan keluarga yaitu <Rp.1.000.000,- adalah 44 responden (98\%) dan yang berpenghasilan >Rp.1.000.000,- adalah 1 responden (2\%).

\section{Pekerjaan Ibu}

Berdasarkan hasil penelitian bahwa pekerjaan ibu swasta adalah 21 responden (47\%), tani ada 3 responden $(6 \%)$ dan yang tidak bekerja ada 21 responden $(47 \%)$.

\section{Jumlah anggota keluarga}

Berdasarkan hasil penelitian bahwa jumlah anggota keluarga 1-3 orang adalah 15 responden (33\%), yang memiliki anggota keluarga 4-6 orang adalah 25 responden (56\%), dan yang jumlah anggota keluarga 7-9 orang adalah 5 responden $(11 \%)$.

\section{Umur Balita}

Berdasarkan hasil penelitian bahwa umur balita kategori <20 bulan adalah 8 balita (18\%), kategori 2040 bulan adalah 14 balita (31\%), dan kategori $40-60$ bulan adalah 23 balita (51\%).

\section{Jenis Kelamin Balita}

Berdasarkan hasil penelitian bahwa jenis kelamin balita perempuan adalah 23 balita (51\%) dan jenis kelamin balita laki-laki ada 22 balita (49\%).

\section{Perbedaan Pola Asuh dan Status Gizi Balita Sebelum dan Setelah Penyuuhan \\ Perbedaan pola asuh sebelum dan setelah}

Hasil penelitian menunjukan bahwa setiap unsur pola asuh mengalami peningkatan pada hasil pengukuran bulan ke-1, bulan ke-2 dan bulan ke-3 dibandingkan pada pengukuran sebelum penyuluhan. (Tabel 1)

Rerata skor pola asuh (pola pemberian makanan sehat) sebelum dilakukan penyuluhan pola asuh hanya mencapai 52.4 poin dan terjadi peningkatan skor pada pengukuran 3 bulan setelah penyuluhan pola asuh sebesar 89.8 poin, (mengalami perubahan sebanyak 17.13\% dibandingkan keadaan sebelum dilakukan penyuluhan pola asuh). Rerata skor pola asuh (praktek kebersihan dan sanitasi lingkungan) sebelum dilakukan penyuluhan pola asuh hanya mencapai 62.73 poin dan terjadi peningkatan skor pada pengukuran 3 bulan setelah penyuluhan pola asuh sebesar 85.42 poin, (mengalami perubahan sebanyak 13.61\% dibandingkan keadaan sebelum dilakukan penyuluhan pola asuh).

Rerata skor pola asuh (perawatan balita sakit) sebelum dilakukan penyuluhan pola asuh hanya mencapai 55.27 poin dan terjadi peningkatan skor pada pengukuran 3 bulan setelah penyuluhan pola asuh sebesar 82.84 poin, (mengalami perubahan sebanyak 14.98\% dibandingkan keadaan sebelum dilakukan penyuluhan pola asuh).

Hasil uji paired t-test menunjukkan terdapat peningkatan yang bermakna skor pola asuh (pola pemberian makanan sehat, praktek kebersihan dan sanitasi lingkungan dan perawatan balita sakit) antara keadaan sebelum penyuluhan gizi dengan keadaan 3 bulan setelah penyuluhan pola asuh $(p=0.001)$. (Tabel 2, Tabel 3, dan Tabel 4).

\section{Perbedaan Status Gizi Balita Sebelum dan Setelah Penyuluhan}

Berdasarkan hasil Z-skor status gizi balita sebelum dilakukan penyuluhan pola asuh hanya mencapai 1.30 poin dan terjadi peningkatan status gizi balita pada pengukuran 3 bulan setelah penyuluhan pola asuh sebesar 0,43 poin, yaitu mengalami perubahan sebanyak $29.53 \%$ dibandingkan keadaan sebelum dilakukan penyuluhan pola asuh. Hasil uji Paired t-test menunjukkan ada peningkatan yang bermakna skor status gizi antara keadaan sebelum penyuluhan pola asuh dengan keadaan 4 bulan setelah penyuluhan pola asuh $(\mathrm{p}=0.001)$. (Tabel 5).

Pengaruh penyuluhan pola asuh (pola pemberian makanan sehat, praktek kebersihan dan sanitasi lingkungan serta perawatan balita sakit) sebelum dan setelah terhadap peningkatan status gizi balita

Berdasarkan hasil penelitian pengaruh pola asuh dalam pola pemberian makanan sehat sebelum dan 
setelah terhadap peningkatan status gizi balita menunjukkan bahwa nilai peningkatan mean dan standar deviation yaitu 316.5 dan 372.78. Hasil Uji Bivariate Correlation didapat nilai pearson correlation sebesar 0.249 sehingga menunjukkan ada pengaruh yang signifikan antara pola pemberian makanan sehat terhadap peningkatan status gizi balita dengan nilai $\mathrm{p}=0.02$. (Tabel 6).

Tabel 1. Rerata Skor PPMS, PKSL, serta PABS

\begin{tabular}{lccc}
\hline \multirow{2}{*}{ Waktu Pengukuran } & \multicolumn{3}{c}{ POLA ASUH } \\
\cline { 2 - 4 } & PPMS & PKSL & PABS \\
\hline Sebelum Penyuluhan $\left(\mathrm{O}_{0}\right)$ & $52.40 \pm 13.07$ & $62.73 \pm 7.06$ & $55.27 \pm 12.95$ \\
Setelah Bulan ke-1 $\left(\mathrm{O}_{1}\right)$ & $68.27 \pm 10.87$ & $73.29 \pm 5.53$ & $63.22 \pm 8.01$ \\
Setalah Bulan ke-2 $\left(\mathrm{O}_{2}\right)$ & $80.60 \pm 8.13$ & $79.96 \pm 6.00$ & $76.24 \pm 7.99$ \\
Setelah Bulan ke-3 $\left(\mathrm{O}_{3}\right)$ & $89.80 \pm 8.91$ & $85.42 \pm 7.82$ & $82.84 \pm 10.82$ \\
\hline
\end{tabular}

Sumber : Data primer Skor PPMS, PKSL, serta PABS

Tabel 2. Peningkatan Penyuluhan Pola Asuh PPMS (Pola Pemberian Makanan Sehat)

\begin{tabular}{lccc}
\hline \multicolumn{1}{c}{ Waktu pengukuran } & Mean \pm SD & Peningkatan & p \\
\hline Sebelum penyuluhan $\left(\mathrm{O}_{0}\right)$ & $52.40 \pm 13.07$ & & \\
$\left(\mathrm{O}_{1}\right) 1$ bulan setelah penyuluhan & $68.27 \pm 10.87$ & $15.87 \pm 23.14$ & 0.000 \\
Sebelum penyuluhan $\left(\mathrm{O}_{0}\right)$ & $52.40 \pm 13.07$ & & \\
$\left(\mathrm{O}_{2}\right)$ 2 bulan setelah penyuluhan & $80.60 \pm 8.13$ & $28.2 \pm 21.2$ & 0.000 \\
Sebelum penyuluhan $\left(\mathrm{O}_{0}\right)$ & $52.40 \pm 13,07$ & & \\
$\left(\mathrm{O}_{3}\right) 3$ bulan setelah penyuluhan & $89.80 \pm 8.91$ & $37.4 \pm 21.98$ & 0.000 \\
\hline
\end{tabular}

Sumber : Data primer Kuesioner Penyuluhan Pola asuh PPMS

Tabel 3. Peningkatan Penyuluhan Pola Asuh PKSL

\begin{tabular}{llcc}
\hline \multicolumn{1}{c}{ Waktu pengukuran } & \multicolumn{1}{c}{ Mean \pm SD } & Peningkatan & p \\
\hline Sebelum penyuluhan $\left(\mathrm{O}_{0}\right)$ & $62.73 \pm 7.06$ & & \\
$\left(\mathrm{O}_{1}\right) 1$ bulan setelah penyuluhan & $73.29 \pm 5.53$ & $10.56 \pm 12.59$ & 0.000 \\
Sebelum penyuluhan $\left(\mathrm{O}_{0}\right)$ & $62.73 \pm 7.06$ & & \\
$\left(\mathrm{O}_{2}\right) 2$ bulan setelah penyuluhan & $79.96 \pm 6.00$ & $17.23 \pm 13.06$ & 0.000 \\
Sebelum penyuluhan $\left(\mathrm{O}_{0}\right)$ & $62.73 \pm 7.06$ & & \\
$\left(\mathrm{O}_{3}\right) 3$ bulan setelah penyuluhan & $85.42 \pm 7.82$ & $22.69 \pm 14.88$ & 0.000 \\
\hline
\end{tabular}

Sumber : Data primer Kuesioner Penyuluhan Pola asuh PKSL

Tabel 4. Peningkatan Penyuluhan Pola Asuh PABS

\begin{tabular}{lllc}
\hline \multicolumn{1}{c}{ Waktu pengukuran } & \multicolumn{1}{c}{ Mean \pm SD } & \multicolumn{1}{c}{ Peningkatan } & p \\
\hline Sebelum penyuluhan $\left(\mathrm{O}_{0}\right)$ & $55.27 \pm 12.95$ & & \\
$\left(\mathrm{O}_{1}\right)$ 1 bulan setelah penyuluhan & $63.22 \pm 8.01$ & $7.95 \pm 20.96$ & 0.000 \\
Sebelum penyuluhan $\left(\mathrm{O}_{0}\right)$ & $55.27 \pm 12.95$ & & \\
$\left(\mathrm{O}_{2}\right)$ 2 bulan setelah penyuluhan & $76.24 \pm 7.99$ & $20.97 \pm 20.94$ & 0.000 \\
Sebelum penyuluhan $\left(\mathrm{O}_{0}\right)$ & $55.27 \pm 12.95$ & & \\
$\left(\mathrm{O}_{3}\right)$ 3 bulan setelah penyuluhan & $82.84 \pm 10.82$ & $27.57 \pm 23.77$ & 0.000 \\
\hline
\end{tabular}

Sumber : Data primer Kuesioner Penyuluhan Pola asuh PABS

Tabel 5. Peningkatan Z-skor dengan indikator BB/TB

\begin{tabular}{lccc}
\hline \multicolumn{1}{c}{ Waktu Pengukuran } & Status gizi & Peningkatan & p \\
\hline Sebelum Penyuluhan $\left(\mathrm{O}_{0}\right)$ & $1.30 \pm 1.28$ & & \\
Setelah Penyuluhan bulan ke-4 $\left(\mathrm{O}_{1}\right)$ & $0.43 \pm 1.26$ & $0.9 \pm 2.54$ & 0.000 \\
\hline
\end{tabular}

Berdasarkan hasil penelitian pengaruh pola asuh dalam praktek kebersihan dan sanitasi lingkungan sebelum dan setelah terhadap peningkatan status gizi balita menunjukkan bahwa nilai peningkatan mean dan standar deviation yaitu 73.21 dan 14.93. Hasil Uji Bivariate Correlation didapat nilai pearson correlation sebesar 0.240 sehingga menunjukkan ada pengaruh yang signifikan antara praktek kebersihan 
dan sanitasi lingkungan terhadap peningkatan status gizi balita dengan nilai $\mathrm{p}=0.02$. (Tabel 6)

Berdasarkan hasil penelitian pengaruh pola asuh dalam perawatan balita sakit sebelum dan setelah terhadap peningkatan status gizi balita menunjukkan bahwa nilai peningkatan mean dan standar deviation yaitu 68.19 dan 19.58. Hasil Uji Bivariate Correlation didapat nilai pearson correlation sebesar 0.279 sehingga menunjukkan ada pengaruh yang signifikan antara perawatan balita sakit terhadap peningkatan status gizi balita dengan nilai $\mathrm{p}=0.008$. (Tabel 6).

Tabel 6. Pengaruh penyuluhan pola asuh (pola pemberian makanan sehat, praktek kebersihan dan sanitasi lingkungan, serta perawatan balita sakit) terhadap peningkatan status gizi balita

\begin{tabular}{|c|c|c|c|c|c|}
\hline \multicolumn{2}{|c|}{ Waktu Pengukuran } & \multirow{2}{*}{$\begin{array}{r}\text { Mean } \pm \text { SD } \\
317.37 \pm 371.45\end{array}$} & \multirow[t]{2}{*}{ Peningkatan } & \multirow{2}{*}{$\begin{array}{c}\text { Pearson } \\
\text { Correlation }\end{array}$} & \multirow[t]{2}{*}{$\mathbf{p}$} \\
\hline $\begin{array}{l}\text { PPMS sebelum dan } \\
\text { penyuluhan pola asuh }\end{array}$ & setelah & & & & \\
\hline $\begin{array}{l}\text { SG sebelum dan } \\
\text { penyuluhan pola asuh }\end{array}$ & setlah & $0.87 \pm 1.33$ & $316.5 \pm 372.78$ & 0.249 & 0.02 \\
\hline $\begin{array}{l}\text { PKSL sebelum dan } \\
\text { penyuluhan pola asuh }\end{array}$ & setelah & $74.08 \pm 13.60$ & & & \\
\hline $\begin{array}{l}\text { SG sebelum dan } \\
\text { penyuluhan pola asuh }\end{array}$ & setelah & $0.87 \pm 1.33$ & $73.21 \pm 14.93$ & 0.240 & 0.02 \\
\hline $\begin{array}{l}\text { PABS sebelum dan } \\
\text { penyuluhan pola asuh }\end{array}$ & setelah & $69.06 \pm 18.25$ & & & \\
\hline SG sebelum dan & setelah & $0.87 \pm 1.33$ & $68.19 \pm 19.58$ & 0.279 & 0.008 \\
\hline
\end{tabular}

Sumber : Data Primer Pengaruh Penyuluhan Pola asuh PPMS, PKSL, serta PABS terhadap peningkatan status gizi balita

\section{PEMBAHASAN}

\section{Tingkat Pendidikan Ibu}

Menurut Soekirman dalam materi Aksi Pangan dan Gizi nasional (Depkes RI, 2000), faktor yang menyebabkan kurang gizi sebagai penyebab langsung sehat, praktek kebersihan dan sanitasi lingkungan, serta perawatan anak balita sakit. Faktor-faktor tersebut sangat terkait dengan faktor gizi ekternal dan faktor gizi internal. Faktor gizi eksternal adalah faktor-faktor yang berpengaruh diluar diri seseorang, yaitu tingkat pendidikan ibu, tingkat pendapatan keluarga, pekerjaan ibu dan jumlah anggota keluarga. Faktor gizi internal adalah faktor-faktor yang menjadi dasar pemenuhan tingkat kebutuhan gizi seseorang, yaitu umur anak balita dan jenis kelamin anak balita (Apriadji, 1986).

Pada penelitian ini masih banyak ibu anak balita yang berpendidikan rendah bahkan ada yang sampai tidak tamat SD sehingga pengetahuan ibu juga kurang baik dalam pengasuhan anak balitanya. Menurut Adisasmito (2007), unsur pendidikan ibu berpengaruh pada kualitas pengasuhan anak, apabila ibu berpendidikan lebih baik maka mengerti cara pola pemberian makanan sehat, menjaga praktek kebersihan dan sanitasi lingkungan, menggunakan pelayanan kesehatan.

\section{Tingkat Penghasilan Keluarga}

Berdasarkan data tingkat penghasilan keluarga dalam penelitian ini lebih banyak keluarga yang tingkat pendapatannya < Rp. 1.000.000,- sedangkan kebutuhan hidup semakin meningkat setiap harinya, sehingga sangat berpengaruh pada penyediaan makanan anak balita. Menurut Adisasmito (2007), di Indonesia dan negara lain menunjukan bahwa terdapat hubungan timbal balik antara kurang gizi dan kemiskinan. Kemiskinan merupakan penyebab pokok akar masalah gizi buruk, proporsi anak gizi kurang dan gizi buruk berbanding terbalik dengan pendapatan. Semakin kecil pendapatan penduduk, semakin tinggi presantase anak yang kekurangan gizi sebaliknya semakin tinggi pendapatan semakin kecil presentase gizi buruk.

\section{Pekerjaan Ibu}


Berdasarkan data pekerjaan ibu dapat diketahui bahwa lebih banyak ibu bekerja dari pada yang tidak bekerja, hanya saja lebih banyak ibu yang bekerja di pabrik sebagai buruh dari pada yang lain. Pekerjaan memiliki hubungan yang erat dengan pendidikan dan pendapatan serta berperan penting dalam kehidupan sosial ekonomi dan memiliki keterkaitan dengan kesehatan. Ibu dengan pendapatan rendah biasanya memiliki rasa percaya diri yang kurang dan memiliki akses terbatas untuk berpartisipasi pada pelayanan kesehatan dan gizi, seperti Posyandu, Bina Keluarga Balita dan Puskesmas, sehingga beresiko tinggi memiliki anak yang kurang gizi (Sukarni 1994).

Menurut Satoto (1990), ibu rumah tangga yang tidak bekerja di luar rumah untuk mencari nafkah secara otomatis memiliki waktu yang lebih banyak untuk mengasuh dan merawat anak. Ibu yang bekerja di luar rumah akan menaikkan nilai sosialnya, namun pada saat yang sama ibu yang bekerja mengakibatkan menurunnya kesehatan anak balita.

\section{Jumlah Anggota Keluarga}

Berdasarkan Tabel 4.4 banyak keluarga yang memiliki jumlah anggota lebih dari 5 orang dalam rumah, bahkan ada yang dalam satu rumah terdapat dua anak balita dan juga ada yang dalam satu rumah terdapat 3 kepala keluarga. Jumlah anggota keluarga dan banyaknya anak dalam keluarga akan berpengaruh terhadap tingkat konsumsi pangan, jumlah anggota keluarga yang besar dibarengi dengan distribusi pangan yang tidak merata sehingga menyebabkan anak dalam keluarga mengalami kekurangan gizi (Husin, 2008).

\section{Umur Anak Balita}

Faktor umur merupakan salah satu faktor gizi internal yang menentukan tingkat kebutuhan zat gizi anak. Pada usia anak balita terjadi pertumbuhan dan perkembangan yang sangat pesat sehingga kebutuhan gizi tiap satuan berat badan relatif lebih tinggi daripada kelompok usia lainnya (Depkes, 2003). Jika pada saat usia anak balita diperkenalkan makanan yang beraneka ragam akan berpengaruh baik terhadap status gizinya. Dukungan gizi sangat berarti, karena dengan gizi sesuai kebutuhan, pertumbuhan fisik dan perkembangan dini ini membentuk dasar kehidupan yang sehat dan produktif (Retno, 2009).

\section{Jenis Kelamin Anak Balita}

Menurut Nix (2005) jenis kelamin telah menjadi dasar segmentasi yang umum digunakan pada berbagai produk. Hal ini disebabkan karena ada perbedaan selera dan kesukaan antara pria dan wanita (Fauzia, 2010). Dalam penelitian ini ditemukan lebih banyak anak perempuan lebih banyak dari pada lakilaki, tetapi tidak dilihat produk apa yang disukai oleh perempuan.

Menurut baku standar WHO-NCHS dalam Retno (2009) jenis kelamin memepengaruhi ukuran tubuh anak yaitu laki-laki lebih berat dan lebih tinggi dari perempuan pada umur yang sama dalam keadaan status gizi baik. Sehingga kebutuhan zat gizi laki-laki lebih tinggi daripada perempuan karena perbedaan luas tubuh dan aktifitasnya.

\section{Perbedaan Pola Asuh dan Stattus Gizi anak Balita Sebelum dan Setelah Penyuluhan Pola Pemberian Makanan sehat (Sebelum sesudah)}

Pola pemberian makanan sehat meliputi frekuensi pemberian makan $\geq 3$ kali sehari, pola hidangan makanan, mendampingi anak waktu makan, selalu memberikan lauk setiap anak makan, selalu memberikan sayur setiap anak makan, membujuk anak agar mau makan, tidak memberi jajanan seperti kerupuk, permen, minuman berwarna. Dari pertanyaan tersebut skor yang mengalami peningkatan hanya sedikit baik sebelum maupun sesudah penyuluhan adalah pada pertanyaan tidak memberikan jajanan dan selalu memberikan sayur setiap kali makan. Artinya penyuluhan di Desa secara berkala tentang makanan sehat dan aman dikonsumsi sangat penting.

Perbedaan pola pemberian makanan sehat sebelum dan sesudah kegiatan pendampingan pola asuh ibu sangat berbeda makna dan mengalami peningkatan $60 \%$, yang tadinya ibu hanya menyiapkan makanan monoton atau tidak bervariasi tapi sekarang menjadi bervariasi. Sehingga kegiatan pendampingan pola asuh ibu dapat memperbaiki pola asuh ibu dalam pola pemberian makanan sehat.

Praktek Kebersihan dan sanitasi lingkungan (Sebelum Setelah).

Praktek kebersihan meliputi air yang dikonsumsi untuk memasak, penyimpanan air untuk memasak, 
cara penyiapan bahan makanan yang baik, selalu mencuci alat makan dan minum menggunakan air dan sabun, anak dimandikan minimal 2 kali sehari, selalu menggunakan sabun pada saat mandi, menggunakan sampho minimal 1 kali seminggu, mengganti pakaian anak minimal 1 kali sehari, selalu cuci tangan sebelum makanan, memotong kuku minimal sekali seminggu, selalu memakaikan alas kaki ketika anak bermain di luar rumah, menggunkan sabun setiap kali selesai BAB. Dan sanitasi lingkungan meliputi pembuangan limbah, jenis sumur yang digunakan, memiliki jamban keluarga dalam rumah, memiliki tembat pembuangan sampah, memiliki vantilasi yang cukup, lantai rumah, memiliki tempat penampungan air, tempat penampungan air yang digunakan, membersihkan tempat penampungan air, pembakaran sampah minimal 2x seminggu. Rerata skor menunjukkan peningkatan baik sebelum dan maupun setelah penyuluhan pola asuh. Pertanyaan selalu memakaikan alas kaki ketika anak bermain diluar rumah sedikit menunjukkan adanya peningkatan karena masih ada beberapa yang tidak melakukananya. Penyuluhan tentang praktek kebersihan dan sanitasi lingkungan di Desa secara kontinyu sangat diperlukan.

Perbedaan praktek kebersihan dan sanitasi lingkungan sebelum dan setelah kegiatan pendampingan pola asuh ibu sangat berbeda makna dan mengalami peningkatan $50 \%$, yang tadinya selalu membiarkan anaknya mempunyai kuku panjang tapi sekarang lebih sering memotong kuku anak balitanya. Sehingga kegiatan pendampingan pola asuh ibu dapat mempernbaiki pola asuh ibu dalam praktek kebersihan dan sanitasi lingkungan.

\section{Perawatan Balita Sakit}

Perawatan balita sakit meliputi penyakit anak dalam sebulan terakhir, langsung membewa anak ke pelayanan kesehatan terdekat jika anak sakit, pelayanan kesehatan yang sering dikunjungi, langsung memberikan obat untuk anak bila anak sakit, mendampingi anak selama sakit, membawa anak setiap bulan ke posyandu untuk ditimbang. Pertanyaan membawa anak setiap bulan ke posyandu untuk ditimbang sedikit menunjukkan adanya peningkatan karena masih ada beberapa yang tidak melakukananya. Penyuluhan tentang perawatan balita sakit di Desa secara kontinyu sangat penting.

Perbedaan perawatan balita sakit sebelum dan setelah kegiatan pendampingan pola asuh ibu sangat berbeda bermakna dan mengalami peningkatan $50 \%$, yang tadinya ketika anak balita sakit tidak pernah ditunggu tapi sekarang ketika anak balita sakit selalu ditunggu. Sehingga kegiatan pendampingan pola asuh ibu dapat memperbaiki pola asuh ibu dalam perawatan balita sakit.

\section{Status Gizi Balita}

Perbedaan status gizi balita sebelum dan setelah kegiatan pendampingan pola asuh ibu sangat berbeda makna dan mengalami peningkatan $30 \%$, yang tadinya mengalami gizi kurang sekarang menjadi normal. Meskipun masih ada 1 balita dari 45 anak balita yang mengalami gizi kurang, dikarenakan dalam satu keluarga ada 2 balita sehingga yang satu kurang terurus oleh orang tuanya, selain itu juga pendapatan keluarga yang kurang dan jumlah anggota keluarga yang sangat banyak juga sangat mempengaruhi status gizi balita. Sehingga kegiatan pendampingan pola asuh ibu dapat meningkatkan status gizi balita.

Hasil penelitian menunjukkan bahwa program penyuluhann pola asuh yang dilaksanakan di Desa Bangsri dan Desa Karang Kecamatan Karangpandan Kabupaten Karanganyar tahun 2013 dapat meningkatkan status gizi balita. Hasil penelitian ini sejalan dengan hasil penelitian Sirajuddin (2007) dalam penelitiannya tentang penerapan model tungku dalam pendampingan gizi di Kabupaten Selayar Sulsel tahun 2006 yang melaporkan bahwa penerapan model tungku mampu meningkatkan status pertumbuhan kelompok intervensi sebesar 28.6\%. Program pendampingan gizi di Kabupaten Selayar mampu meningkatkan asupan zat gizi balita sekaligus menggambarkan adanya perbaikan pola pengasuhan gizi pada kelompok intervensi setelah dilakukan pendampingan selama 3 bulan.

Pola pemberian makanan sehat pada balita harus bertahap dan bervariasi, dari mulai bentuk bubur cair kebentuk bubur kental, sari buah, buah segar, makanan lumat, makanan lembek dan akhirnya makanan padat (Arisman, 2010). Studi-studi tentang status gizi menunjukkan adanya hubungan antara pola asuh ibu dalam pola pemberian makanan dan status gizi balita. Sesuai dengan pendapat Moehji (1998), yang menyatakan bahwa pola pemberian makanan yang kurang tepat dapat menyebabkan terjadinya kekurangan gizi dan pemberian yang berlebihan akan terjadi kegemukan.

Pengaruh penyuluhan pola asuh (pola pemberian makanan sehat, praktek kebersihan dan sanitasi 
lingkungan serta perawatan balita sakit) sebelum dan setelah terhadap peningkatan status gizi balita

Berdasarkan hasil Uji Bivariate Correlation menunjukkan ada pengaruh yang signifikan antara pola pemberian makanan sehat terhadap peningkatan status gizi balita $(\mathrm{p}=0.002 ; \mathrm{r}=0.249)$. Hasil penelitian ini diperkuat oleh hasil penelitian yang dilakukan Yulia dkk (2008), yang menyatakan bahwa perilaku selama memberikan makan atau pola asuh makan oleh ibu berhubungan positif dan signifikan dengan status gizi balita. Ditambahkan, bahwa pola asuh makan yang baik lebih tinggi persentasenya pada responden yang ibunya tidak bekerja (65.0\%) dari pada ibu yang bekerja (38.1\%). Hasil uji statistik menunjukkan terdapat hubungan yang bermakna antara pola asuh makan dengan status pekerjaan (Melva, 2006)

Hasil penelitian ini sejalan dengan yang dikemukakan oleh Yamnur Mahlia (2009), bahwa tidak ada hubungan antara jenis makanan dengan pertumbuhan dan perkembangan bayi. Surbakti (2005) menyatakan bahwa perkembangan sebagai indikator penilaian status gizi seorang anak tidak dipengaruhi oleh jenis makanan yang diberikan oleh orang tuanya, tetapi lebih ditekankan pada cara orang tua memberi makanan kepada anaknya sehingga anaknya mau makan.

Hasil penelitian lain yang mendukung hasil penelitian ini adalah penelitian Lubis (2008) yang melakukan penelitian hubungan pola asuh berdasarkan praktek pemberian makan dengan status gizi menunjukan ada hubungan yang signifikan antara praktek pemberian makan dengan status gizi balita. Sedangkan menurut Inayati, dkk (2012) praktek pemberian makanan yang disesuaikan dengan kepercayaan tradisional daerah asal sangat mempengaruhi status gizi balita.

Perilaku makan anak, pemantauan dan pembatasan makanan anak paling sering dan konsisten dikaitkan dengan penambahan berat badan balita (Clark dkk, 2007). Menurut Adnan dan Muniandy (2012), menyatakan bahwa ada hubungan anatara praktek pemberian makanan anak dengan status gizi sesuai dengan tingkat pendididkan ibu.

Usaha kesehatan pribadi merupakan bentuk pencegahan sehingga terhindar dari penyakit yang dapat menurunkan derajat kesehatan. Indonesia menerapkan hal ini sebagai bentuk paradigma sehat baru yaitu upaya kesehatan yang lebih ditekankan pada upaya-upaya yang bersifat preventif dan protektif untuk mewujudkan Visi Indonesia Sehat 2010 (Manda dkk, 2006).

Entjang (1985) mendefinisikan usaha kesehatan pribadi sebagai daya upaya dari seorang demi seorang untuk memelihara dan mempertinggi derajat kesehatannya sendiri. Usaha-usaha tersebut dapat dilakukan antara lain dengan memelihara kebersihan, makan makanan yang sehat, cara hidup yang teratur, meningkatkan daya tahan tubuh, menghindari penyakit, meningkatkan kecerdasan, melengkapi rumah dengan sarana kebersihan, dan melakukan pemeriksaan kesehatan.

Sanitasi lingkungan merupakan kegiatan untuk melindungi kesehatan manusia melalui pengendalian, pengelolaan dan pencegahan faktor lingkungan yang menganggu kesehatan. Penyakit diare umumnya terjadi pada daerah yang memiliki sanitasi lingkungan yang buruk. Ruang lingkup kesehatan lingkungan tersebut antara lain mencakup sumber air, kebersihan jamban, pembuangan sampah kondisi rumah, pengelolaan air limbah. Lingkungan merupakan segala sesuatu yang mengelilingi kondisi luar manusia atau hewan yang menyebabkan penularan penyakit. Kombinasi faktor perilaku dari masyarakat yang kurang dan lingkungan, yang bila musim hujan lebat hampir $2 / 3$ wilayah tergenang air juga memperburuk sanitasi. Berdasarkan penelitian Rochman (2010) diketahui bahwa ada hubungan antara sanitasi lingkungan dengan kejadian diare. Sanitasi lingkungan yang dimaksudkan dalam penelitian tersebut meliputi sumber air, jenis jamban, kebersihan jamban, pengelolaan air limbah dan pembuangan sampah.

Berdasarkan hasil Uji Bivariate Correlation menunjukkan ada pengaruh yang signifikan antara praktek kebersihan dan sanitasi lingkungan terdapat peningkatan status gizi anak balita $(\mathrm{p}=0.002 ; \mathrm{r}=0.240)$. Hasil penelitian ini diperkuat oleh hasil penelitian Gabriel (2008), yang menyatakan bahwa praktek kebersihan lingkungan yang dilakukan oleh ibu berhubungan positif dan signifikan dengan status gizi anak balita.

Hasil penelitian lain yang mendukung ada hubungan yang signifikan antara praktek kebersihan dan sanitasi lingkungan dengan status gizi anak balita (Ayu, 2008). Sanitasi dan kebersihan air merupakan intervensi untuk mengurangi penyakit menular dan dapat berpengaruh dalam peningkatan status gizi anak balita (Dangour dkk, 2013). Pelayanan kesehatan setempat dan kondisi sanitasi dan kebersihan sumber air dianggap sebagai penentu penting dalam peningkatan status gizi anak balita (Kamiya, 2011).

Perawatan adalah kasih sayang yang diberikan ibu kepada anak untuk membantu pertumbuhan, menggendong, memeluk dan berbicara kepada anak akan merangsang pertumbuhan dan meningkatkan 
perkembangan perasaan anak. Rasa aman pada anak akan tumbuh apabila ia selalu berada dengan ibunya dan memperolah air susu ibu sesuai dengan kebutuhan dan apabila sakit ibu selalu menyimpan obat dan membawa ke rumah sakit atau pelayanan kesehatan (Depkes RI, 2002).

Praktek perawatan kesehatan anak dalam keadaan sakit adalah salah satu aspek pola asuh yang dapat mempengaruhi status gizi anak, membaik praktek pengasuhan kesehatan adalah hal-hal yang dilakukan untuk menjaga status kesehatan anak, menjauhkan dan menghindarkan penyakit serta dapat menyebabkan turunnya keadaan kesehatan anak. Praktek perawatan kesehatan meliputi pengobatan penyakit pada anak apabila si anak menderita sakit dan tindakan pencegahan terhadap penyakit sehingga anak tidak sampai terkena suatu penyakit. Praktek perawatan kesehatan anak yang baik dapat ditempuh dengan cara memperhatikan keadaan gizi anak, kelengkapan imunisasi, kebersihan diri anak dan lingkungan dimana anak berada, serta upaya ibu dalam hal mencari pengobatan terhadap anak apabila sakit ibu membawa anak ke tempat pelayanan kesehtan seperti rumah sakit, klinik, puskesmas, polindes (Zeitlin, 2000).

Berdasarkan hasil Uji Bivariate Correlation menunjukkan ada pengaruh yang signifikan antara perawatan anak balita sakit terhadap peningkatan status gizi anak balita $(\mathrm{p}=0.008 ; \mathrm{r}=0.279)$. Hasil penelitian ini berkaitan dengan hasil penelitian Lubis (2008), yang melakukan penelitian hubungan pola asuh berdasarkan praktek kesehatan dengan status gizi menunjukan ada hubungan yang signifikan antara praktek kesehatan dengan status gizi anak balita.

Hasil penelitian ini sejalan dengan yang dikemukakan oleh Yamnur Mahlia (2009), bahwa tidak ada hubungan antara perawatan dengan pertumbuhan dan perkembangan bayi. Masalah gizi kurang dapat diperbaiki jika balita mendapatkan pola asuh perawatan yang baik. Hal ini sesuai dengan penelitian yang dilakukan oleh Hamidah (2006), yang menyatakan ada hubungan pola asuh perawatan dengan status gizi. Perilaku sigap dalam perawatan anak balita sakit sangat mempengaruhi status gizi dan dapat mengurangi angka kematian dalam jangka pendek (Najnin dkk, 2011).

\section{KESIMPULAN}

Semakin Sering diadakan kegiatan penyuluhan pola asuh (pola pemberian makanan sehat, praktek kebersihan dan sanitasi lingkungan, serta perawatan balita sakit) akan dapat meningkatkan status gizi balita.

\section{UCAPAN TERIMA KASIH}

Ucapan Terimakasih Dinas Kesehatan Kabupaten Karangannyar Jawa Tengah dan Puskesmas Desa Bangsri dan Desa Karang yang telah mendukung terlaksananya kegiatan penelitian ini. Terimakasih juga saya ucapkan kepada Ibu dan balita di Desa Bangsri dan Desa Karang Kecamatan Karangpandan Kabupaten Karanganyar Jawa Tengah yang telah bersedia menjadi sampel dalam penelitian.

\section{REFERENSI}

Adisasmito, W, Sistem Kesehatan Nasional, Rajagrafindi Persada, Jakarta. 2007.

Dangour AD, Watson L, Cumming O, Biosson S, Che Y, Velleman Y, Cavill S, Allen E, and Uauy R. Interventions to improve quality and supply, sanitation and hygiene practices, and their effects on the nutritional status of children. Cochrane Database of Systematic Reviews. The Cochrane Library 2013, Issue 8. Art. No.: CD009382.

Depkes RI, 2007. Profil Kesehatan Indonesia, Jakarta. Dep.Kes RI , 2010. Profil Kesehatan Indonesia, Jakarta. Dep.Kes RI

Dinas Kesehatan Kabupaten Karanganyar, 2012. Profil Kesehatan Kabupaten Karanganyar. Di Kabupaten Karanganyar.

Dinas Kesehatan Provinsi Jawa Tengah, 2011. Profil Dinas Kesehatan Jawa Tengah. Di Jawa Tengah.

Gabriel, A. 2008. Perilaku Keluarga Sadar Gizi (kadarzi) serta Hidup Bersih dan Sehat Ibu Kaitannya dengan Status Gizi dan Kesehatan Balita di Desa Cikarawang Bogor. [Skripsi] Bogor : Institut Pertanian Bogor.

Hamidah, Nur. (2006). Hubungan Pola Asuh Gizi, Kejadian Infeksi, Tingkat Konsumsi Energi Dan Protein Dengan Status Gizi Pada Bayi Usia 0-12 Bulan Di Wilayah Kerja Puskesmas III Mranggen Kabupaten Demak, Available:

http://www.fkm.undip.ac.id/data/index.php?action=4\&idx=2863.

Inayati DA, Scherbaum V, Purwestri RC, Hormann E, Wirawan NN, Suryantan J, Hartono S, Bloem MA, 
Pangaribuan RV, Biesalki HK, Hoffmann V, and Bellows AC, 2012. Infant feeding practices among mildly wasted children: a retrospective study on Nias Island, Indonesia. International Breastfeeding Journal. Vol 7 : 3. Hal 1-9.

Khomsan A. 2000. Teknik Pengukuran Pengetahuan Gizi. Bogor: Institut Pertanian Bogor.

Kamiya Y, 2011. Socieconomic Determinants of Nutritional Status of children in Lao PDR: Effects of Household and Community Factors. Journal Health Population Nutrition. Vol. 29, No. 4, pp. 339-348.

Lubis R. 2008. Hubungan Pola Asuh Ibu dengan Status Gizi Anak Balita di Wilayah Kerja Puskesmas Pantai Cermin Kecamatan Tanjung Pura Kabupaten Langkat Tahun 2008. Skripsi FKM USU, Medan.

Mahlia, Yamnur. 2009. Pengaruh Karakteristik Ibu dan Pola Asuh Makan terhadap Pertumbuhan dan Perkembangan Bayi di Kecamatan Pangkalan Susu Kabupaten Langkat Tahun 2008. Tesis. Medan: Universitas Sumatera Utara.

Melva V. 2006. Hubungan Pola Asuh Dengan Status Gizi Anak Batita Di Kecamatan Kuranji Keluerahan Pasar Amabacanmg Kota Padang Tahun 2004. (Skripsi) . Medan: Universitas Andalas.

Najnin N, Bennett CM, and Luby SP. 2011. Inequalities in Care-seeking for Febrille Illness of Under-five Children in Urban Dhaka, Bangladesh. Journal Health Population Nutrition. Vol. 29, No. 5, pp. 523531

Notoatmodjo, S. 2010. Metodologi Penelitian Kesehatan, Jakarta: Rineka Cipta.

Rochman T.B. 2010. Hubungan Sanitasi Lingkungan dengan Kejadian Diare pada Balita di Kecamatan Jatipuro Kabupaten Karangannyar. Skripsi Fakultas Ilmu Kesehatan Universitas Muhammadiyah Surakarta.

Salimar, 2005. Peranan Penyuluhan dengan menggunakan leaflet terhadap perubahan pengetahuan dan sikap ibu Balita Gizi Kurang. Puslitbang gizi dan Makanan Bogor.

Sirajuddin, 2007. Pengaruh model tungku terhadap Status Gizi Anak Usia 12-59 Bulan di Kabupaten Selayar, Tesis. Program Pasca Sarjana Unhas, Makassar.

Sunarti, E 2004. Mengasuh dengan Hati Tantangan yang Menengah, Jakarta Media Kompotido.

Surbakti. 2005. Pola Pengasuhan dan Status Gizi Balita Ditinjau dari Karakteristik Ibu (Skripsi). Medan: Universitas Sumatera Utara.

WHO. 2004. Water, Sanitation and Hygiene Links To Health. http://www.who.int. [Mei 2008]

WHO. 2007. Water, Sanitation, and Hygiene. Geneva: WHO

Yamnur, M. 2009. Pengaruh Karakteristik Ibu dan Pola Asuh Makan Terhadap Pertumbuhan dan PerkembanganBayi di Kecamatan pangkalan susu Kabupaten langkat Tahun 2008. Medan. USU.

Yulia C. dkk. 2008. Pola Asuh Makan dan Kesehatan Anak Balita pada Keluarga Wanita Pemetik Teh di PTPN VIII Pangalengan. Tersedia di : id.pdfsb.com/jurnal+kesehatan+pada+balita. Diakses pada 3 Februari 2012.

Zeitlin, M 2000. Balita di Negara-Negara Berkembang, Peran Pola Asuh anak, Pemanfaatan Hasil Studi Penyimpanan Positif untuk Program Gizi. Prosiding Widyakarya Nasional Pangan dan Gizi uVII. Kerjasama LIPI Bappenas, UNICEF, Deptan, BPS. Jakarta. 